\title{
Third Party Logistics Service Marketing and Economic Development (Study of the Speed Mail Businesses in Nigeria)
}

\author{
Oko, A. E. Ndu ${ }^{1, *} \&$ Ogba Ike-Elechi ${ }^{2}$ \\ ${ }^{1}$ Department of Marketing, Abia State University, Uturu, Nigeria \\ ${ }^{2}$ Department of Marketing, Ebonyi State University, Abakaliki, Nigeria \\ *Corresponding author: Department of Marketing, Abia State University, Uturu, Nigeria. \\ Tel: 234-805-785-1630 E-mail: a.e_nduoko@yahoo.com \\ Received: December 16, $2013 \quad$ Accepted: January 7, $2014 \quad$ Online Published: February 17, 2014 \\ doi:10.5430/mos.v1n1p32 \\ URL: http://dx.doi.org/10.5430/mos.v1n1p32
}

\begin{abstract}
Nigeria is relatively under developed with its indices as poor standard of living, high cost of living, high unemployment rate and low per capita income, thus economic development is retarded. The third party logistics service marketing in some developed and developing economies generate employment thus contributes to economic development based on its infrastructure base. This work studied the situation in Nigeria based on selected speed mail business firms and their clients in major service industries of the country. Findings include the inappropriate marketing mix service blending, high incidence of taxes on service providers by government, lack of understanding of the market, regulatory inadequacies among others. Thus recommends as solution to the operational inadequacies of these businesses, are the adoption of strategies of good service quality determination, service quality management, and efficiency in service branding, quality service positioning and value in message creation in content, context and structure as well as the creation and sustenance of viable network referral structure among others.
\end{abstract}

Keywords: third party logistics, economic development, regulatory environment, cost of operation, service branding, referral network and life cycle marketing

\section{Introduction}

Marketing logistics as an aspect of the physical distribution is managed based on the principle of supply chain of inflow and outflow, whose output is service delivery to defined target market(s). Logistics functions as cost centre of corporate operations is managed based on the concept of total logistics cost; involving transportation, warehousing and storage, packaging, material handling, inventory control, order processing, customer service level, plant and warehouse site locations and management as well as return goods handling.

Logistics activities are services rather than goods oriented; hence are managed for customer satisfaction based on customer service concept given the ability of the service providers to meet the needs to the target market in terms of time, dependability, communication and convenience-a compendium of research in customer service(1994). Given this, customers value delivery services in terms of: on-time delivery, quick delivery, after order placement and effective handling of problems-Gooley (1996).

Good logistics programme should aim at reducing the stress in material acquisition through effective process of re-ordering and receiving product based on electronic data base and inventory system of quick response and efficient consumer response-Levy and Weitz (1998); dependability, with respect to consistent lead time, safe delivery and complete delivery of material for the purpose of achieving just-in-time delivery programme-Berkowitz, Kerin, Hartley and Rudelius (2000); good quality two-way- communication link between the buyer and seller through efficiency in the monitoring of services and anticipation of future needs of target market; and convenience as a means of reducing the efforts spent by the buyers in their business relationship with the sellers. To achieve these, as indices of customer service standards, organizations have often entered into partnership with third -party logistics service providers; who perform most or all the logistics functions that manufacturers, suppliers and distributors would normally performed themselves-Lieb and Maltz (1998). These third party logistics services providers in a bid 
to institutionalize a more proactive flow of useful information improve on-time deliveries.

The speed mail 'services' as an integral of the transportation system in Nigeria is a member activity in physical distribution and logistics management and is commonly managed under the third party logistics service providers programme among first class business organizations in different industrial sectors of the Nigerian economy like the banking and finance; construction; manufacturing; health; breweries; building materials; food, beverages and tobacco, petroleum (marketing); conglomerates and chemical and paints industries.

\section{Objectives of This Study}

This work is aimed at appraising for efficiency and effectiveness or otherwise, the integration of the service components and characteristics of market offer in the marketing of speed mail 'services' as an integral of the (logistics) transportation system in Nigeria. Hence addressed sub-issues of:

- The role and contributions of speed mail sub industry in the growth and development of the transportation sector and macro economy of Nigeria, and

- The challenges of the speed mail services industry in Nigeria,

\section{Significance of the Study}

Studies in this field include Ogbonna (2011), that reviewed speed mail services as integral of the transportation system in Nigeria. This work dwelt on power (electricity) supply, funding, government policies, human resources, mechanical breakdown among others as limiting factors to the operational efficiency of courier services operation in Nigeria, and NIPOST (2011), that exposed challenges of firms in the courier industry in Nigeria to include multiple taxation on courier service providers by different Federal and State government agencies, disparity in claims over a range of items damaged on transit, ex-orbitant charges for the movement of items among others.

Literature in the area of the effect of proper integration of marketing principles in target market identification and offer positioning given the service nature of speed mail business for consumer satisfaction and corporate profitability as indices of growth and development of the transportation sector and the macro economy of Nigeria is not available. This gap area as satisfied makes this work significant.

\section{Research Hypotheses}

This study is based on a single hypothesis stated in non form thus:

$\mathbf{H}_{0}$ : The non integration of marketing principles into speed mail services marketing does not challenge the growth and development of the transportation sector and the macro economy of Nigeria.

\section{Literature}

\subsection{Core Issues in Contemporary Logistics}

Logistics operationally and conceptually as differentiated from material management is an integration of functions of transportation, warehousing, packing and packaging, with its extension of containerization, shipping, customerized processing, delivery, logistics information and other associated operations common in product, transfer between destinations-Jianhua (2013). These functions thought independent in operations are synthesized for close relationship for the purpose of operational efficiency in the supply chain management, thus its operation is method based and technology oriented; with focus for modern management concept and integrated management approach-www.jrte.net/jrtr29/f52-jiahtml.

Modern logistic allows the service provider participate in the management and administration of client's business in respect to its series of activities unlike the traditional concept; hence logistics service providers designs the logistics plans and offers comprehensive service needed in the supply chain. This specialist service of the logistics service provider leads to reduction in operational cost for the client, thus corporate profitability of the client is enhanced. It is also acceptable to opine that the logistics service provider in performing client's logistics functions creates profit margin for itself-Jianhua (2013). Authorities in marketing share the opinion that the practice of modern logistics based on logistics operator offer services that actualize client's goals and objectives based on the optimization of overall logistics functions performance and the maximization of client's profit through across cost minimization in 
all logistics activities-Lieb (2013), Hertz (2003) and Www.Inboundlogistics.Com/--/2013-3pl--Perspeetives-Ctrafling-A-Blueprin--.Modernlogistics therefore is concerned with serve and integrated management of the entire supply chain -Jianhua (2013).

\subsection{Logistics in Micro and Macro Economics}

Internally in most firms, logistics activities have high impact on production, especially based on developments production technologies as associated costs as well as cost of acquisition of technical know how needed for logistics management between the various logistics activities leads to cost minimization and subsequently serves as a good source of profit and productivity enhancement-Bangguo (2013). Firms engaged in the provision of logistics functions consider associated activities of logistics a sources of income and a centre for the creation of employment-www.ppiaf.org./freight triki/knowledge.map/logistics-efficiency; as logistics has become an advanced form of organization and management technology-jianhua (2013).

Externally logistics is considered a catalyst in economic development especially given its role in industrial marketing as a spearhead activity in the supply chain. It is considered basis of shaping and sharpening inter and intra industrial competition and for the integration of different economies into a global market. It is as well considered an impetus to activities that macro societal economic growth and development.www.ppiaf.org.freighttooikit/knowledge-map/logistics/market.

\subsection{The Third Party Logistics Activities and the Future}

Logistics firms that provide services as independent organizations are referred to as the third party. Given the specialized nature of logistics management, firms depend on third party agents for these services, especially as the contract relationship frees firms to concentrate on their core functions based on the integration of other internal resources for customer satisfaction; as technology for inbound and outbound as well as reverse logistics and associated information outside the firm are obtained in contract relationship terms-www.sch.gatch.edu/research/supply-chain/2009.

In the some developed economics, third party logistics services include warehousing, transportation, packaging and others that extend to the provision of services associated with the physical movement of goods, provision and framework for customers' overall corporate strategic and operational management based on designing of comprehensive logistics system, formulation of general plans for the management of supply chain and the super intending of clients operational decisions and activities-www.capGemini-com/resources-file-/3pl-sudy-report-web-version.pdf. 2014.

This collaborative relationship between the service providers and the clients that is built on the designing of the logistics system and actual performance of logistics functions on behalf of the clients is tailored for the long term period for the maximization and optimization of the benefits of this relationship. Thus, it generates corporate stability, system actualization and continuity in the planning and management of organization's supply chain for the clients and long term period of engagement ensures stabilized source of income-Jianhua (2013).

Firms in the third party logistics services in Nigeria are more in the speed mail business.

\subsection{Structure of Speed Mail Business in Nigeria}

Development in the transport sector of the Nigeria economy that result from the desire among firms to delivers logistics services at minimum cost to the consumers attracted firms in the courier service provision like UPS supply chain solutions, DHL logistics and Fedex logistics services. These firms could not expand their operation beyond the level of national infrastructural growth and development with services as basis for operational efficiency, thus their impacts have remained low in both the international and domestic sectors of the Nigeria society. To break even for survival, these firms concentrated on foreign mail services provision. Nigeria Post as a compliment joined the courier industry with its speed post in 1986, with its target as domestic services; with its charges relatively low compared to the foreign competitors. Nipost is involved in collection, dispatching and distribution of inland mail parcels or merchandise at a reasonable cost, as it also operates facilities for remittance of money through the money or postal order system referred to as post cash, based on the internet network technology transfer system-Nigeria Communication Commission (2005).

Currently the number of firms in the courier services industry has increased as almost all major firms in the transportation industry have affiliates or subsidiaries engaged in the movement of parcels for customers as their third party logistics services providers. Common among these are Ifex Express Delivery Services, ABC luggage services, Peace Express Delivery Services, Red Star Express Plc among others. 
It is unfortunate to remark that inspite of the growth in number of these courier agents (local and foreign), the mailing industry is yet to record remarkable contribution to the development of the transportation system and the macro economy of Nigeria, nor has it made acceptable impact in its goal of satisfying the logistics needs of the customers at minimum acceptable cost.

Preliminary research results in this area show that these firms' (local and foreign) operation lack marketing principles, philosophies, policies and strategies; hence, the obvious inability to identify their supposed target market(s) for proper positioning of offer.

\subsection{Speed Mail Activities}

Common activities of speed mail services providers are complex and are beyond delivery of packages. They include complex logistics process of purchase orders, inventory, order status checks, invoice, payment, returned merchandise and delivery of vehicles. These firms also manage information and money flow between businesses and businesses as well as between persons and persons. Timely information are required for trackling the movement of items on transit, as are considered strategic for the creation and sustenance of competitive advantages.

Speed mail service providers manage logistics activities of their clients, as area of competence; thus allow these clients concentrate on their core areas of business. Logistics service range from ground to air passage distribution, freight delivery-(air, ocean, rail and road) and mail services to inventory management, logistics management softwares and e-commerce solutions as well as financing -Kotler and Armstrong (2010).

Speed mail services in the area of financing include, management of clients account receivables for settlement (reimbursement) and receiving payments from recipients, collection of credit services for small and medium scale businesses and provision of funds inventory, equipment leasing and asset financing.

In the area of consultancy services, speed mail organizations provide advice and technical resources as required by larger, medium and small scale businesses as are needed in improving corporate logistics programme efficiency. These advisory services are also in the area of redesigning of corporate logistics system to align same with business strategies as means of aiding customers synchronize the flow of their goods, funds and information vertically and horizontally along the supply chain. Other areas of services include supplies of softwares that improve client's distribution efficiency inclusive of street -level -route optimization, territory planning, mobile delivery execution, real-time wireless dispatch and tracking of goods in transit-Kotler and Armstrong (2010).

These services of the speed mail services providers could be bundled in a complete system service as part of products supply chain to include logistics, transportation, freight and customer brokerage services for smooth corporate operations-www.ups.scs.com/solutions/case-studies/cs-nikon.pdf(2008) and Roger (2007).

\subsection{Role of Speed Mail Services Providers in Macro Economic Development}

Speed mail services providers in aggregate contribute to the social economic development of many economies of the world. As loops - (open and close) in the logistics and supply -chain management, these firms aid marketing create utilities-form, place, value and (ownership) possession that enhance the standard of living of the populace, they serve as employers as well as source of revenue through the service rendered, spur marketing to identifying and satisfying the needs of target market based on exchange relationships at profit. In the process of creating utilities, the speed mail services providers develop and sustain infrastructure base that serves as hub of operations. These services create merchant class which serves as means of creating and sustaining bilateral relationships between nations of the world. These roles of the speed mail service providers are seen in the following-Kotler and Armstrong (2009).

- UPS has the resources to handle the logistics needs of just about any size of business. It employs 425,300 people, some 93, 600 vehicles (package cars, vans, tractors and motorcycles), 600 owned and chartered aircraft and more than 1,000 warehouse facilities in 200 countries," thus firm UPS contributes to 6 percent of the GDP of US as it links 1.8 million sellers with 6.1 million buyers each day, thus processes more than 46 million electronic transactions every week. These speed mail services firms also serve 90 percent of the world population and 99 percent of the businesses in the fortune 1000 and invest 11 billion a year in information technology to support its highly synchronized by -the-clock logistics service. It is equally on records that UPS provides customers information in all and every process of transaction with 700 international freights per day to and fro 377 countries of the world- UPS ensures the timely delivery of courier business documents, prototypes, high value goods and emergency repair parts to different firms in different parts of the world, on daily basis. 
Based on these activities of the speed mail services providers, marketing and its practice is assisted in stimulating demand to meet supply level of the industrial sector of most economies of the world, hence production and productivity is re-enforced.

In closing the loop in marketing activities, speed mail services providing firms are involved in the process of reclaiming recycling and re-usable materials, returns and rework from the point of consumption or use for repair, remanufacturing or disposal. Third party logistics partnership between the speed service providers and manufacturing firms has contributed reasonably in the management of the physical environment of nations, hence economic and ecological dividends secured as solid waste management costs and their environmental impact of landfills are reduced-Berkowitz, Kerin, Hartley and Rudelius (2000) and Doug (1998).

Comparatively, given the population of Nigeria estimated at 140 million, with 34 Federal, 34 State, 39 private sector and 57 other degree awarding universities; 45 Federal, 139 state, 20 private sector polytechnics and 6 colleges of health; and 21 Federal, 47 state and 41 private sector colleges of Education. In the banking and other finance industrial sector of the economy, there exist -22 banks with over 7000 branches; 18 insurance carriers brokers and security firms, numerous micro finance banks and 6 (six) other financial institutions. The consumer goods sectors has 1(0ne) automobile and spare part firm, 5 (five) beverage-brewers/distilizers, 3 (three) non-alcoholic beverage firms, 7 (seven) food producing firms, 2 (two) food products- diversified firms, 1(one) household durable, 2 (two) personal household producing firms.

In the construction /real estate sector are 4 (four) major firms; the conglomerates has 4 (four) diversified industries and agricultural sector has 3 firms in the sub area of crop production and on (1) in the area of livestock and animal specialty.

The health care industry has 1 (one) major firm in the sub area of medical supplies and 5 (five) in the pharmaceuticals, and in the industrial goods industry are 9 (nine) firms in the building material sub sector, one (1) in electronic and electric products and 2 (two) in packaging and containers, while in the natural resources sector are 1 (one) in the chemical, and 1(one) in metals construction, and in the information communication technology sector is one (1) firm.

The oil and gas industry has one (1) firm each in the energy equipment and service and integrated oil and gas service and 7 (seven) firms in petroleum and petroleum products sub sector.

In the service industry are one firm each in the advertising, automobile/auto part retailer; courier/freight and delivery, employment solutions and road transportation sub sectors respectively, two (2) firms in the transport related services and 3 (three) firms in the printing and publishing sub industries respectively and 3 (three) firms in the hoteland lodging sub sector-stock market update (2013: 6:28). These statistics are restricted to firms quoted and are do trade on the floor of the Nigeria stock market. Based on the integration of the activities of firms that are not quoted in the stock exchange market and those of the Ministries, public sector-(government-corporations) and institutions at the Federal, state and local government levels as well as the 36 states, 746 local government areas including the Federal Capital Abuja, it could be discovered that the speed mail delivery services sector of the transportation industry is grossly under developed, thus is not positioned to satisfy the specialized and general target markets of Nigeria, thus has relatively not contributed to the macro economic development of Nigeria compared to other nations of the world.

This relative backwardness of the speed mail service provision in Nigeria is the subject of investigation and analysis in this research work.

\section{Methodology}

Questionnaire were administered to the research targets as academic, banking, construction industry, healthcare, conglomerates, building material, natural resources, oil and gas, the service industry, Government-Federal, state and local at Ministry levels, Institutions and parastatals based on the scale of weight -(importance) and usage of the services of speed mail firms and to the speed mail service providers.

Respondents were spread across the six geo-political zones of Nigeria but with special recognition of business density ratio and the contribution of the different industries and sectors to the economic development of the country.

This, as a survey (descriptive research), established the impact of the speed mail business as a component of the service industry in the economic development of Nigeria. Samples of firms were collected from the different industries and sectors of the economy based on judgemental sampling techniques, while sample size were determined based on the yard mathematical notation of: 


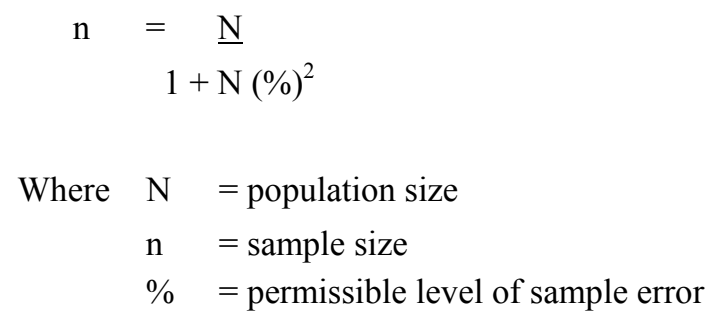

Questionnaire as were administered on selected firms (speed mail service providers and their corporate clients) was at the rate of 3 (three) natural persons per firm and to natural clients of the service providers yielded $78 \%$ and $74 \%$ and $62 \%$ return rates respectively and validity rates of $75 \%$ and $71 \%$ and $59 \%$ respectively were established based on the pre and post test method-Ezejelue, Ogwo and Nkamnebe (2007).

The data as collected and collated were structured based on Likert scale and comparison was on Pearson Correlation co-efficient "R" - Febara and Mguni (1995) and Ezejelue, Ogwo and Nkamnebe (2009) represented thus:

$\mathrm{r}_{\mathrm{xy}}=\frac{\sum(\mathrm{x}-\overline{\mathrm{x}})(\mathrm{y}-\overline{\mathrm{y}})}{\mathrm{n}^{\mathrm{s}} \mathrm{s}_{\mathrm{y}}}$

Where: $\quad x$ and $y$ are each values of $x$ and $y$

$\bar{x}$ and $\bar{y}$ are mean values of $x$ and

$\mathrm{s}_{\mathrm{x}}$ and $\mathrm{s}_{\mathrm{y}}$ are standard deviation of $\mathrm{x}$ and $\mathrm{y}$

$\mathrm{n}$ is the number of paired values.

\section{Analysis}

The analysis of the data generated based on the administered copies of questionnaire is shown in table 1 thus:

Table 1. Response on Questions in the Administered Questionnaire

\begin{tabular}{|c|c|c|c|}
\hline Items of evaluation & $\begin{array}{c}\text { X Speed mail } \\
\text { Service } \\
\text { providers }\end{array}$ & $\begin{array}{l}Y_{1} \text { Corporate } \\
\text { Clients }\end{array}$ & $\begin{array}{c}\mathbf{y}_{2} \text { Natural } \\
\text { Clients }\end{array}$ \\
\hline $\begin{array}{ll}\text { - } & \text { Quality of Service Offer } \\
\text { - } & \text { Reliability } \\
\text { - } & \text { Responsiveness } \\
\text { - } & \text { Assurance } \\
\text { - } & \text { Empathy } \\
\text { - } & \text { Tangibility }\end{array}$ & $\begin{array}{l}.60 \\
.65 \\
.58 \\
.48 \\
.58 \\
(.58)\end{array}$ & $\begin{array}{l}.50 \\
.50 \\
.41 \\
.36 \\
.42 \\
(.44)\end{array}$ & $\begin{array}{l}.30 \\
.25 \\
.30 \\
28 \\
30 \\
(.24)\end{array}$ \\
\hline $\begin{array}{ll}\text { - } & \text { Service Profit Chain } \\
\text { - } & \text { Internal service quality } \\
\text { - } & \text { Satisfied and productive service employee } \\
\text { - } & \text { Greater service value } \\
\text { - } & \text { Satisfied and loyal customers } \\
& \text { Healthy service profit growth }\end{array}$ & $\begin{array}{l}.51 \\
.58 \\
.62 \\
.57 \\
.60 \\
(58)\end{array}$ & $\begin{array}{l}.35 \\
.42 \\
.41 \\
.42 \\
.48 \\
(.41)\end{array}$ & $\begin{array}{l}.22 \\
.30 \\
.28 \\
.29 \\
.30 \\
(.28)\end{array}$ \\
\hline $\begin{array}{l}\text { - Internal Marketing } \\
\text { - Employee development training } \\
\text { - Good quality recruitment experience } \\
\text { - Communication } \\
\text { - Administration, delegation of authority or }\end{array}$ & $\begin{array}{l}.56 \\
.48 \\
.58 \\
.52\end{array}$ & $\begin{array}{l}.42 \\
.36 \\
.51 \\
.42\end{array}$ & $\begin{array}{l}.36 \\
.29 \\
.30 \\
.28\end{array}$ \\
\hline
\end{tabular}




$$
\text { responsibility }
$$

- Other motivational incentives.

- Interactive Marketing

- $\quad$ Service delivery

- $\quad$ Skill of personnel

- Impact of ICT on service delivery

- Personnel interaction with client service differentiation

- Service quality

- Service productivity

- Targeting of Market

- Mass market

- Differentiated market

- Niche marketing

- Customerization

Service Position

- Differentiation of offer

- Head-to-head position

- Closing of Sales

- Designing of proposition

- Delivery of proposition

- Development of Institutional capacities

- Discovery of Satisfaction gap

- Diagnosis of the identified gap

- Management of Marketing Element of Service

- Exclusivity

- $\quad$ Branding

- Capacity management

- Management of Marketing Element of Price

- $\quad$ Peak pricing

- $\quad$ Off peak pricing
.40

(.50)

.59

.60

.52

.58

.52

$.56(.55)$

.30

.42

.38

.26

(34)

.40

.60

(.52)

.52

.46

.40

.30

.20

(.46)

.38

.40

.52

(.43)

.50

.50

(.50)

.25

.60

(.43)
.31

(.40) 


\section{Base on table 1:}

- Employees and management personnel of the various speed mail service providers valued the quality of speed mail services delivery in Nigeria at 58\% efficiency, while the corporate and natural clients valued this efficiency at $44 \%$ and $24 \%$ respectively. Thus service providers and service consumers have differences in the evaluation of efficiency in speed mail services delivery. While the service providers value the efficiency at $58 \%$, the consumers have $34 \%$ as efficiency rate in service provision.

- In the area of service profit chain, the contribution of these services to corporate profitability of the speed mail services providers is estimated at $58 \%$, while the consumers have $35 \%$ as the contribution of these services to the profit of the mail service providers. This poor level of contribution of speed mail services to profitability suggests why the number of firms in this industry is still comparatively low inspite of the vast number of sectors and firms who need the services of the speed mail firms.

- The speed mail services providers generally have low level of appreciation and application of internal marketing policies and strategies. This is rated by corporate personnel at $50 \%$. The clients who have the direct impact of these internal marketing policies and strategies activities rate these speed mail firms at $35 \%$ efficiency in policies and strategies application.

- Interactive marketing activities that show the front line staff skill and competency in services delivery given service productivity, quality and differentiation is rated at 55\% level efficiency among the personnel and management of speed mail services providers and $34 \%$ by consumers of services of these firms. Data also show that the speed mail services providing firms are poor in market targeting activities, while corporate personnel assessed the organizations' efficiency rate at $34 \%$, consumers of the services evaluated these service providers at $28 \%$.

- In the area of service positioning, the speed mail services providers were assessed at $50 \%$ rate of efficiency by their staff and management while clients have $35 \%$ rate of assessment of these services providers. It is also discerned that the speed mail services providers have poor ability at closing sales. They were assessed at $46 \%$ efficiency on this index by corporate personnel and at $25 \%$ by services consumers.

- These firms (speed mail services providers) are poor in the management of elements of marketing of services, promotion, distribution and price and pricing policies and strategies. While the corporate personnel assessed operational efficiency in the management of these elements of marketing at $43 \%, 50 \%, 43 \%$ and $33 \%$ respectively, clients (consumers) assessed these indices at 26\%,36\%, 28\% and $17 \%$ respectively.

To test for the acceptance or otherwise the research hypothesis projected, the hypothesis is re-structured for null and alternative thus:

$\mathrm{H}_{0}$ : The non integration of marketing principles into speed mail service marketing does not challenge significantly the growth and development of the transport sector of Nigeria.

$\mathrm{H}_{0}$ : The non integration of marketing principles in the speed mail service marketing does challenge significantly the growth and development of the transport sector of Nigeria.

Adopting and substituting the variables concerned into the mathematical notation of:

$$
r_{\mathrm{xy}}=\frac{\sum(\mathrm{x}-\overline{\mathrm{x}})(\mathrm{y}-\overline{\mathrm{y}})}{\mathrm{ns}_{\mathrm{x}} \mathrm{s}_{\mathrm{y}}}
$$

is based on data on table 2 
Table 2. Assessment of the Rate of Efficiency in Adoption of Marketing Principles in Speed Mail Services Marketing in Nigeria

\begin{tabular}{lcc}
\hline \multicolumn{1}{c}{ Items of evaluation } & $\begin{array}{c}\text { Corporate service } \\
\text { Providers } \\
\text { \% }\end{array}$ & $\begin{array}{c}\text { Clients } \\
\text { (Consumers) } \\
\text { \% }\end{array}$ \\
\hline - Quality of service offer & 58 & 34 \\
- Service profit chain & 58 & 35 \\
- Internal marketing & 50 & 35 \\
- Interactive marketing & 55 & 34 \\
- Serket targeting & 34 & 28 \\
- - losing of sales & 50 & 35 \\
- Management of service elements & 46 & 25 \\
- Management of price elements/ activities & 43 & 26 \\
- Management of distribution function & 50 & 36 \\
- Management of promotion elements /activities & 43 & 28 \\
\hline
\end{tabular}

Table 3. Required Computations for Calculating $\mathrm{r}_{\mathrm{xy}}$

\begin{tabular}{|c|c|c|c|c|c|c|c|}
\hline & $\begin{array}{l}\text { Efficien } \\
\text { Corpor }\end{array}$ & & $\begin{array}{l}\text { ciency } \\
\text { Imers }\end{array}$ & & & & \\
\hline & $\mathrm{X} \%$ & y\% & $\mathbf{x}-\overline{\mathbf{X}}$ & $(x-\bar{x})^{2}$ & $\mathbf{y}-\bar{y}$ & $(y-\bar{y})^{2}$ & $(x \bar{x})(y-\bar{y})$ \\
\hline & 58 & 34 & 14.5 & 210.25 & 03.7 & 13.69 & .53 .65 \\
\hline & 58 & 35 & 14.5 & 210.25 & 04.7 & 22.09 & 68.15 \\
\hline & 50 & 35 & 06.5 & 42.25 & 04.7 & 22.09 & 30.55 \\
\hline & 55 & 34 & 11.5 & 132.25 & 03.9 & 13.69 & 42.55 \\
\hline & 34 & 28 & -09.5 & 90.25 & -02.3 & 5.29 & 21.85 \\
\hline & 50 & 35 & 06.5 & 42.25 & 04.7 & 22.09 & 30.55 \\
\hline & 46 & 25 & 02.5 & 06.25 & -05.3 & 28.09 & 13.25 \\
\hline & 43 & 26 & -00.5 & 00.25 & -04.3 & 18.49 & 2.15 \\
\hline & 50 & 36 & -06.5 & 42.25 & 05.7 & 32.49 & 37.05 \\
\hline & 43 & 28 & -00.5 & 00.25 & -02.3 & 5.29 & 1.15 \\
\hline & 33 & 17 & -08.5 & 72.25 & -13.3 & 176.89 & 113.05 \\
\hline$\sum x=479$ & $\sum y=333$ & $\sum(\mathrm{x}-\overline{\mathrm{x}})=$ & & & $=360.19$ & & \\
\hline$\overline{\mathrm{x}}=43.5$ & $\bar{y}=30.3$ & & & & & & \\
\hline$r_{x y}=$ & $\sum(x-\bar{x})(y-\bar{y})$ & & & & & & \\
\hline & $\mathrm{nS}_{\mathrm{x}} \mathrm{S}_{\mathrm{y}}$ & & & & & & \\
\hline$=$ & $\underline{413.95}$ & & & & & & \\
\hline & $11(9.21)(6.00)$ & & & & & & \\
\hline$=$ & $\underline{413.95}$ & & & & & & \\
\hline & 607.85 & & & & & & \\
\hline$=$ & $\underline{0.68}$ & & & & & & \\
\hline
\end{tabular}

From the computation, the correlation of 0.68 is established, showing a positive correlation between the assessment of personnel of organizations involved in the provision of speed mail services in Nigeria and consumers of the services on the level of efficiency in the adoption of the principles of marketing in the management of speed mail services in Nigeria. 
Given this positive correlation, it is important to test for the significance of the correlation using student' ${ }^{\prime}$ ' test statistical denoted as:

$$
\begin{aligned}
\mathrm{t} & =\frac{\mathrm{r} / \mathrm{n}-2}{1-\mathrm{r}^{2}} \\
& =\frac{0.68 / 11-2}{1-0.68^{2}} \\
& =\underline{0.68 / 9} \\
1-0.46 & \underline{0.68(3)} \\
& 0.04 \\
& =\underline{2.04} \\
& 0.54 \\
& \underline{3.78}
\end{aligned}
$$

Where $r$ is the value of the Pearson Correlation

$\mathrm{n}$ is the number of paired observations.

To conduct this test, the hypotheses are adjusted thus:

$\mathrm{H}_{0}: \quad \mu=0$ (there is a linear relationship between $\mathrm{x}$ and $\mathrm{y}$ )

$\mathrm{H}_{0}: \quad \mu \neq 0$ (there is no linear relationship between $\mathrm{x}$ and $\mathrm{y}$ )

The value of the t computed is 3.78, at 0.05 level of significant and 9 degrees of freedom, thatis (11-2), has the critical value of the $t$ statistic as 1.833 . The test is significant, thus, the null hypothesis that the is no linear correlation between the assessments of personnel of speed mail services providers and consumers of the services that non integration of marketing principles in the speed mail services marketing does not have significant impact on the growth and development of the transportation sector and macro economy of Nigeria.

\section{Findings and Discussions}

The following as findings of this research work are based on the analysis as presented in section 7

\subsection{General Issues}

Among the general issues are:

- Growth and development in speed mail service delivery in Nigeria is poor, this is based on the fact that service provision is not based on proper assessment of service quality, through service gap analysis which is focused at establishing differences between the consumers' expectations and experience, hence consumers' inputs are not incorporated into mail service offer as their expectations and experiences as target market do not influence decisions on the quality of the mail service offers. Based on this, reliability, responsiveness, assurance, empathy and tangibility as vital integrals of services are not properly highlighted in speed mail services delivery in Nigeria. Dis-satisfied customers thus, influence prospective customers based on word of mouth communication as a dysfunctional promotional activity.

- The practice of customer contact is poor in the speed mail sub sector of the transportation industry in Nigeria. These firms do not spend efforts at developing flow chart of the points of interaction between their customers and touch points of service provision as input for customer contact audit-Clift (1995), Bitner, Booms and Tetrecault (1990), Scheuing (1989) and Susser, Olsen and Wyeroff (1978). Based on the poor adoption of customer contact audit the place of relationship marketing is relegated to the background; hence 
expectations of customers' encounters as opportunities for the development of social bonds as incentives for loyalty are not achieved-Berkowitz, Kerin, Hartley and Rudelius (2000). This accounts for why most firms in the banking industry are involved in the use of self devised mail service delivery programmes devoid of the use of the third party logistics organizations.

- The principles of internal marketing are poorly adopted among speed mail services providing firms in Nigeria, thus expected central role of employees in attracting, building and maintaining relationship with customers-Tansuhji, Randall and McCullough (1998), is poor and does not yield desired returns.

It is expected that the employees as speed mail services providers, should as part of corporate internal marketing efforts and programmes; be involved in employee development through recruitment of high caliber of staff, training, communication and administration. This will motivate the staff of these organizations to effectiveness; rather, most of them appear worm out as they discharge their duties. Demoralize personnel can never motivate client to be interested on their offer.

- The speed mail services as product especially those of indigenous firms unlike their foreign competitors do not warrant special attention, hence so many other small organizations tend to copy the principal players in this industry, thus almost all transportation organizations in Nigeria claim to be providing speed mail services. These firms by the quality of their offer are not able to create exclusiveness of class for themselves. These services as products are poorly branded thus consumers are not positively influenced in consumption decision making processes-Thomas (1998). A close study of Federal Express logistics and DHL logistics, beyond Nigeria reveal strong brand names that convey class distinctiveness and benefits as accruable to consumers as the firms are patronized-Oren (1993) and Berry, Lefkouith and Clark (1988), thus for firms in the speed mail sub sector of transportation industry to survive the weave of competition in this industry, respective management must rise to the challenges of creating acceptable brand names through service delivery, pricing of services and quality relationship marketing activities. This is especially so, given the challenges of marketing services following the characteristics of inseparability and perishability which must be integrated to satisfy the client at profit-Berkowitz, Kerin, Hartley and Rudelius (2000).

- Speed mail service marketing given its low level of development and inability of participants to expand the market, is managed based on the mass market marketing strategy. Firms offer undifferentiated services to the general universal market without regards to niching and customerization and in attempt at positioning corporate offer, are involved in head-to-head positioning as common among the principal players of Fedex, URS and DHL in this sector in Nigeria. This therefore makes operations extremely cost oriented. Hence the act of re-investment of profit for corporate growth and development as well as contribution to national development is seriously being challenged.

- The Nigeria speed mail service marketing is currently being managed based on the arm chair service marketing principles of the money deposit banking industry of the 1980 's, hence these services providers have poor attitude to closing of sales. Sales closure is still been described as the point where the prospect or customer agrees to buy. This is traditional, thus should be considered obsolete-Thull (2013). These activities of closing of sales in the Nigeria speed mail sub sector of the transportation industry are devoid of the principle of multiple decision-mutual understandings-Thull (2013). The input of the target market is not considered relevant in product design and delivery, hence the service providers do not make attempt at discovering the expectations of the target market nor do they diagnosis for deficiencies in their current level of productivity. Customer interactions are not treated as precious resources, nor are cross -functional teams created to deliver compelling experiences. These firms in addition do not develop institutional capacities vital for the identification of important customers so as to be equipped with information to deliver experiences tailored to customers' needs as bridge for the development of good feedback loops.

Also identified is the inability of these firms to align their goals, measures, systems and organizational structures with a view to achieving customer-led organizational efforts that optimize the attributes of the target market at minimized cost-www.bain.com. The adoption of the three sales closing techniques of trail, assumption and urgency create tension in the customers which dis-stabilize the psychology of relationship marketing as the customers are often of the notation that the staff of the speed mail services firms are taking undue advantage of their business relationships-Berkowitz, Kerin, Hartley and Rudelius (2000).

It is also a common observation among speed mail services providers that selling process end with closing of sales as neither the foreign nor indigenous firms in this sector of the transportation industry adopt customer. Follow up strategy which ensures through any other device inclusive -telephone that customers' purchased services have been 
properly delivered. This after sales services ensure repeat sales and generate greater revenue at lower cost compared to attempts at acquiring new customers- sales and marketing management (1995) and -Fortune (1998).

\subsection{Marketing Mix Blending}

Speed mail service providers have not exhibited expected skills in the area of capacity management as no differences exist in the off and on season management of service demand neither are corporate assets managed for maximized return on investment. Price variations are not common in line with seasonal demands variation and market segments-Lovelock (1991).

It is expected that these firms should adopt variations in price of services as variations in demand for services occur along the different seasons of the year especially with the view to spurring up demand during the off pick pricing seasons-Johnson (1997). In the area of distribution, electronic devices are needed to offer customers convenient. This is also not in vogue in Nigeria. These firms spend little or nothing in the promotion of their services hence the availability, location, consistency in quality and efficiency and courteousness in service delivery that ought to be highlighted are not accommodated-Hite, Fraser and Bellizzi (1990), Geogre and Berry (1981) and Johnson, Scheuing and Gaida (1986). These firms are housed in obsolete and moribund buildings in less used streets of most towns in Nigeria.

\subsection{Internal Conditions of Operations}

Interviews and literature reviews show that tax incidences on these firms have been high in different parts of Nigeria especially Lagos, where the Local, State and Federal governments charge these firms various forms of taxes simultaneously as tenement rate, warehouse permit, business premises and advert dues. Hence operational costs are considered high in Nigeria.

Respondents to questionnaire are of the view that Nigeria courier service providers are not marketing concept oriented, especially in the area of interaction with customers, as customers at the desk of registration of parcels are informed that fragile goods are on transit at owners' risk. This is contrary to the service providers' claim that clients in the case of damaged items are advised to write official letters for appropriate actions based on negotiation by parties-Jajah (2011). Even at this, the claimed treatments to customers in cases of lose or damage of items is un-marketing, thus discouraging.

It is observed that cases of mis-routing of items on transit is high, thus the firms with the aid of modern technology of information communication techniques based on tracking (device) system determine incidences of mis-routed mail and cause the items to be re-routed. This process of re-routing mails takes long time thus; clients are expected to monitor their parcels in transit for appropriate complaints at their personal costs.

\section{Challenges in the Courier Service Industry in Nigeria}

The firms in this industry have problems that relate to the determination of service charges. Items in transit are not often charged relative to their risky nature, thus values and propensities to loses and damages are not accorded recognition in the determination of charges. This is inpsite of the fact that loses and damages occur frequently and the firms claim they compensate clients.

Most loses as recorded in goods on transit are attributed to inability to track mis-routed items given constant power outage and consequent inability to secure the service of telephone net work service providers; failure, breakdowns and inability of trucks to arrive at destinations within stipulated times and periods given the deplorable state of federal and state government roads in Nigeria. These have always caused risk of and actual lost of (customers) clients' items in transit

\subsection{Regulatory Environment}

The activities of the courier services providers in Nigeria are by law regulated by the (Nigeria Postal Authority) Nigeria Postal Service who issues operating (licence) certificate of these firms. This sub-sector of the transportation industry is considered relatively profitable, thus has witnessed the inflow of many indigenous firms especially as almost all major transportation companies claim to be providing speed mail services-Jajah (2011). This inflow has expanded the membership of the industry beyond the management capacity of (Nigeria Postal Authority) Nigeria Postal Service, thus these services are not adequately regulated. Many clients have thus, fallen victims of fraudsters in the industry, thus the supposed confidence in speed mail services is gradually being eroded. 


\subsection{High Cost of Operations}

The costs of providing infrastructural basis of operation of the Nigeria courier firms are high. This is in terms of cost of maintaining and operating transportation vehicles, given the poor state of roads, high cost of supply of electricity given constant outage of power and subsequent adoption of generators as source of electricity and associated high cost of petroleum products. High incidence of taxes at all tiers of government as well as high cost of capital as charges by members of the money deposit banking industry. These costs have direct impacts on the per period service charge. Thus considering the high income elasticity of demand among Nigerians, only few natural and artificial persons patronize these firms. To cover cost, for marginal profit differential, service charges are further increased beyond the reach of Nigerians.

\section{Implication of the State of Courier Services for Nigerians}

The underdeveloped state of the courier service firms and their activities is a source of concern to the average Nigerians. Hence the industry requires specific rather than general attention. It is therefore important that an evaluation of the operational indices of these organizations be examined.

\subsection{Scope of Operations}

Apparently, the courier services sub sector of the transportation industry is classified along operational fields of local (domestic) and international. In the international and intercontinental are DHL, UPS, Fedex and in the domestic scene are City Errands, Chase Express Courier Services Ltd, Ifex Express Ltd and ABS Express Courier Services Ltd in the midst of many unregistered firms. While the Nipost Express as domestic transverse other nations beyond Africa for inter-continental operation, the other domestic courier services providers have their impact of the operations felt in other nations of Africa especially West Africa. This shows the narrowness of the operational field of most courier service providers in Nigeria. It is important to note that, the most of these firms if not all, specialized in the delivery of mails and other small size containers as little or no haulage activities as considered.

Given this limited scope of operation of these speeds mail (courier) services providers, it is not possible for the infrastructural base of these firms to be developed, hence the likelyhood of this sector to generate desired level of employment that will contribute significantly to national economic development as low. Based on this, this sector of the economy is not likely to be spurred to enhancing the standard of living of significant number of members of the populace.

\subsection{Lack of Understanding of the Market}

The operations of courier services firms in Nigeria are based on inadequate, poor evaluation and lack of understanding and knowledge of and consumption behaviour of the target market. Hence the influences as considered relevant in the decision making process to adopt or otherwise the services of these firms such as perception, personal, physiological and psychological as internal and economic, cultural, reference groups and sociological as external -David (2002) are not brought to bear in market targeting and product (service) positioning activities of the courier services providers.

Given thus, the target markets' attitude and perception of the service charges of these firms; mode of service delivery and associated qualities of reliability, tangibles, responsiveness, assurance and empathy; method of settlement of services obligations and availability as influences on the decisions of the target market against the offer of these courier services providers are not properly evaluated. Equally important but highly neglected are issues considered sociological such as the industrial sector-firmography; opinion leaders and the influence of word of mouth communication as well as the impact of culture and its associates as beliefs, values and lifestyle which shappen and sharpen the buying decision making process and activities of the target markets.

This lack of understanding of the market by courier service providers has significant negative impact on the ability of the firms to take correct and appropriate decisions on market targeting and product positioning activities, hence the principles and strategies relevant for market segmentation are ignored or are not highlighted. Based on this, the efficiency in the rate adoption of appropriate marketing mix variables for target market satisfaction is low. Continuous operations at this state lack of understanding of the market retards the ability of the firms to realize required profit, and contribution margin for desired catalyst activities needed for national economic development.

\subsection{Regulatory Inadequacies}

The evident growth in number of rather than domestic and international operations oriented firms in the industry without the expected impact of regulation does not only cause decline in the quality of services provided as quack 
practices has continue to be on the increase, causes decline in profitability of corporate operations. Hence expected sums to set aside of internal and interactive (relationship) marketing as basis for effective external marketing have continued to remain low. This accounts for the low practice of service-Quality management that revolves around strategic application of acceptable concepts in marketing, top-level-management commitment to quality, high standard of market offer, adoption of self-service technologies in operations, systems and systematic procedures for maintaining service performances and customer complaints management, and emphased activities of employee satisfaction-Kotler and keller (2009), in the Nigeria courier services sub-industry. Given this, firms in this industry do not have clear sense of their target market and market needs, thus are not good at developing distinctive strategy for satisfying customer needs. This, though is considered costly, has ability of improving corporate-client personal relationship-McGregor (2007); placement of little emphasis on financial returns on investment and more on service performance that attract and sustain customer loyalty; quality differentiation of corporate offer and personality based on the designing and presentation of better and faster service delivery systems that are anchored on reliability, resilience and innovativeness of offer-Kotler and Keller (2009) and Capacino (1997), and technologies that offer consumers value convenience in service as replacement of personal service delivery- Berry, Sciders and Grewal (2002), Bitner (2001) and Meuter, Ostrom, Roundtree and Bitner (2000), especially ascustomers are made to understand their role in the adoption of the technologies of service delivery and the benefits of adopting of the technologies as ability to adopt the technologies is created in the customers-Meuter, Bitner, Ostrom and Brown (2005) and McCormirck (2005). Other area of service quality management of evaluation of services on customer importance and company performance as vital performance analytical tool that rate the various elements of service bundle with identifiable marketing actions required to consummate them and checking same on competitors' performance levels is not also practiced in Nigeria courier service industry-Mortilla and James (1977). Neither do these firms monitor customer complaints for service dis-satisfaction management, hence the desire to achieve higher revenue and greater profit compared to competitors inter and intra industrially as means of addressing service failure is not also in practiced-Blodgett and Anderson (2000) Tax and Brown (2000) and Fornell and Wernerfelt (1998). This accounts for why the practice of service differentiation and development of brand strategies for services as components of brands services management activities is low in the courier service industry. The adoption of strategies aimed at efficiency in the management of product-support services for the development and sustenance of competitive advantages are equally in low practice in this industry. Hence most courier firms in Nigeria compared to those in the developed nations of USA and UK do not have adequate stock of small appliances, office machines, forklifts, trucks, mainframes and air planes and do not provide for service augmentation such that ease ordering, delivering, installation, customer training, customer consulting and maintenance and repair services that serve as bases of service differentiation -Kotler and Keller (2009). Based on these, firms are poor in customer needs-identification and satisfaction-Vardenbosch and Dawer (2002) Lele and Karmarkar (1983), Hici and Tse (1996) and Taylor (1994), hence, they are not involved in the adoption of post sales services activities as follow up. Thus customers' requests, suggestions and complaints are not efficiently managed. The absence of the afore discussed accounts for the paucity in the harnessment of service of comparative advantage as bases of adoption of economies of scale and skill principles among firms in the Nigeria courier service sub industry-Auguste, Harmon and Pandit (2006).

Based on the foregone, it is difficult for firms in the courier service sub-industry to contribute meaningfully to national economic development especially without proper appreciation of speed service business as a service oriented business rather than goods. Courier businesses thus, should be managed based on service lines of thoughts. Hence the following recommendations.

\section{Recommendations}

Development in the service industry globally is driven by de-regulation and development in technology-Berkowitz, Kerin, Hartley and Rudelius (2000). However, contemporarily in Nigeria especially in the courier service sub industry, total de-regulation will lead to increase quack practices and consequent decline in patronage.

Technological development has the propensity to increasing speed and efficiency of delivery, reliability, reduction in size and cost of items in the midst of decline in inter-personal relationship which is the hub of African (cultural) exchange relationship; as customers patronize more, those who have favourable attitude towards them.

Service marketing especially the non-necessity service areas of courier (speed mail), may not be marketed based on the same principles as service in necessary areas like medicine and law. This is basic, given the low level of per capita income and the high level of poverty in Nigeria-World Development Report (2010) and National Bureau of 
Statistics (2012); as well as the high level of income elasticity of demand for luxury and necessary products among greater fraction of population of the active society.

Based on the foregone, this work recommends the following:

\subsection{Good Service Quality Determination}

Consumers are delighted when their expectations concerning market offers are exceeded-Rust and Olivrer (2002), as such they compare the perceived service characteristics with the expected-Voss, Parasuraman and Grewal (1990). Delight may not be created unless these speed mail service consumers are identified based on market targeting principles and are actively segmented according to their needs and social economic characteristics as natural persons and firmography; operating capacity in terms of the technology of operations; purchasing structure and situation as well as personal characteristics of principal personnel-Oko (2013), as artificial persons, for the purpose of embodying in the service offer characteristics that are capable of satisfying the target markets.

Consumer perception evaluation of good quality of courier service should aim at identifying and satisfying expectation gap; as management perception of service is compared with consumer expectation, management perception with service quality specification, service quality specification with service delivery and external communication and perceived service with expected service-Kotler and Keller (2009).

This should be based on good knowledge of the consumption behaviour of the different target markets. Based on this assessment, the service providers should be able to rate reliability responsiveness, assurance, empathy and tangibles as variables that influence satisfaction appropriately. This may be backed up with increasing or decreasing customer expectations on quality of service output with possible improvement of perception of overall service quality-Kotler and Keller (2009).

\subsection{Service Quality Management}

Knowledge of the psychological and physiological variables as components of the consumption behavior of Nigerians in market segments is vital for good courier service quality management. Hence these firms are required to plan their market offers showing obesity for customer satisfaction as top management of firms show commitment to service performance rather than financial performance. This must be with a good sense of optimizing the interest of the customer without compromising those of the firm. Product must also be designed to cause differences to exist between firms' offer and those of competitors based on reliability resilience and innovativeness. This will be made possible at least cost with good multiple decisions -Mutual understanding -Thull (2000) programmes between the firm and the target markets. These programmes ought to show respect for vertical and horizontal information flow between the personnel at the consumer touch points of the organizations internally and the consumers externally, using up to date technology of service which are affordable and within the (reach of customers) and the service knowledge of the target market, as service satisfaction evaluation indices are set up and consumer complaints monitored for least cost impacts on the firms. These service management activities may not yield required returns without good quality personnel motivation that is capable of creating job satisfaction and commitment in-personnel to pampering customers; for fair appraisal and evaluation of customer needs, development of personal relationship with customers and the delivery of quality service to meet the needs of customers and beyond for delight-Domovan, Brown and Mowen (2004).

Given this, firms in the Nigeria courier service sub industry are expected to invest in internal marketing activities-Gronroos (1984) and Gilly and Wolfinbarger (1988) as pre-requisite for interactive marketing-Gronross (1984), Berry, L. (1986), Singh (2000), Hauser, Simester and Birger (1996), Grene, Walts and Schrest (1994)-Jong, Ruyter and Lemmank (2004) and Hartline and Ferrell (1996) and for successful execution of external (relationship) marketing activities.

\subsection{Efficiency in Service Branding}

For most Nigeria courier service consumers, no marked difference exist between DHL, UPS, Fedex, ABC courier, Ifex courier and others. This is because the service contents in core, augments and symbol are the same across these mail service providers. Hence this work recommends the introduction of service brands, built on skillful augmental variables that are capable of differentiating corporate offer from those of competitors. Differentiation features could be built along the principal elements of marketing and their intra variables as well as the role of personnel in the rendering of these services. Service differentiation generates virtues of functional rather dysfunctional publicity and word of mouth communication as the services are public relationship oriented-Barrett (2005) and Marconi and Macfarland (2002). 
Though brand characteristics (features) are subject to copy by competitors especially in the service industry, but in the money deposit banking industry in Nigeria banks brand their product based on the colour or painting of their building and styles as well as uniform worn by members of auxiliary staff. This has even been extended to banks official vehicles, and format for deposit and withdrawal slips. For good quality branding in the courier service industry in Nigeria, these firms are expected to be careful in the choice of brand elements in logo, symbols and characters as well as slogans as these are necessary to create tangibility in the benefits associated with the mail service offer. Brand names should improve the image of the firms as they are expected to personify the organizations. Service firms in branding are expected to design their marketing communication and information in content, context and structure to create in the target market, the desire to know more about the firm -kotler and Keller (2009).

Service branding activities of firms in the courier service industry do not recognize personification of service providers; hence do not emphasis cooperation, hard work, trustworthiness as well as competency and knowledge as virtues - Tarter (2002). To achieve personified attributes in the courier service firms, firms should be named after reputable persons. Where this is not possible or not necessary; firms should invent characters and showcase top talent in the firms' management term as they play prominent role at seminars, group meeting and shows; and should be visibly highlighted in firms' websites; as people are considered the power features of a service product -Tarter (2002).

Branding in the Nigeria courier service industry should permit product positioning and targeting of different market segments as price and service contents are considered bases for distinguishing different segments of the market as the nature and caliber of personnel and their training and technological support programme, are highlighted.

Personnel of FedEX beyond Nigeria as a part of branding strategy almost always seem trim-looking and eager compared with those of their major and minor competitors who look out of shape and unmotivated-Tarter (2002).

\subsection{Service Positioning and Sales Message}

Target markets are attracted to courier service providers, like in other service industries by the service marketing firms chemistry, personality, expertise and the potential for a long term relationship-Tarter (2002). Though these virtues are not in display in service marketing as they are in goods marketing, the Nigeria courier service providers rather than develop good quality service positioning and sales messages, depend on satisfied and repeat customers whom they assume know what they a re buying. Even at this, these satisfies customers do not have the words to describe the quality of the services they had enjoyed, thus service providers relying on word of mouth communication, are unable to maximize their market and sales potentials because word of mouth communication are incoherent as such are useless as source of lead-Tarter (2002). To achieve efficiency in service positioning and sale message, the courier service providers must create value promotion to showcase the benefits of depending on their services. This must stress the availability, location, consistent quality, and efficient and courteous services-Onkvisit and Shaw (1989), as characteristics of their offers. Hence messages must identify core services in offer and should sum the value created or in anticipation in few words that can not be ignored by customers, and show present claims built on what experts in the firms had achieved and are able to achieve. Message must present personalities, candor, enthusiasm, humor and perhaps a flash of eccentricity. These as qualities found people who know they are best in their field should be highlighted. Promotion incentives should also be packaged and targeted at the ultimate service consumers, providers of ancillary services and members of the work force as employees. This is considered a means of making an abstract service tangible, thus is able to embody value. Firms in the courier service industry as part of service tokens that boost renewal rate are encouraged to sponsor seminars and trainings for members of general and specific publics as well as be involved in events marketing - Tarter (2002) and Oko (2013).

\subsection{Create and Sustain Referral Network}

Firms in the courier service business in Nigeria must strive at creating relationships with natural and artificial persons opinion leaders, who serve as service ambassadors, and based on word of mouth communication-(Buzz marketing), influence others to consume the service. Public relations and events marketing activities of the courier service organizations that create publicity could also be made available to the buzz groups. These programmes take advantage of social networking processes as consumers spread information about the service within and beyond defined social marketing communities.

Creation and Sustenance of referral network may involve inspiring defined segments of the service market to gossip the corporate offer by causing a particular activity to be carried out regularly for the purpose of causing amazement in the defined markets, encouraging customers to talk to each other about specific features of the market offer, treating loyal customers specially through extension of sales promotion incentives and the organization of talk and 
workshops, conferences and seminars that create opportunities for principal customers and prospects and personal of the firms, to exchange view on specific features of the organisations' offer-Tarter(2002).

\subsection{Building on the Concept of Life Cycle Marketing}

Service marketing is built on the concept of maximization of life -time relationship that is open ended and anchored on series of assignments, subscriptions and long term contracts. These valued long term relationships yield trust, familiarity and cost savings advantages.

Based on the principle of life cycle marketing, clients are exposed to experience of service offer as stimulant for favourable purchase decisions and are compensated for dissatisfactory service performances as a means of eliminating the possibilities of customer switch. This is inpsite of the fact that service standards are almost not defined.

In addition to these, speed mail services providers are advised to develop variety of activities aimed at attracting and holding current and potential consumers. These are based on efficiency in the adoption of sales promotion incentives, guarantees, premiums, and trail periods which are targeted at reducing customers' perception of risk as basis for commencement of relationships.

Incentives packages are vital for efficiency in the management of target market commitment anxiety which is needed for the realization of marketing economies in the reduction of the cost of selling, renewals and add ons, as such variables on price of services are less important. Ability to secure life cycle marketing advantages is measured by the firms' ability to increase profit over time with growth in service sales volume and value.

Achievement service life cycle marketing advantages depend on efficiency in the adoption of the tactics of progressively disclose of sales portfolio, building of retention campaigns, appointment and efficiency in the deployment of services of relationship managers for the management of services customers dis-satisfaction as well as efficiency in the management of the span or length of the customer relationship-Tarter (2002). Customer relationship management is measured for efficiency, based on the rate of renewal of service contract relationships.

\section{Limitations}

This work though intensive and expansive is neither exhaustive nor comprehensive; thus may not serve the purpose of generalization. It is/was also influenced by the poor attitude of Nigerians as natural and artificial persons to questionnaire as source of primary data.

\section{Area of Future Research}

Further study could be executed in the area of warehousing and or the haulage sector(s) of logistics, in relation to other industries in specification not general, especially with bias for the attitude of Nigerians for third party logistics services.

\section{References}

A Compendium of Research in Customer Service (1994). International Journal of Physical Distribution and Logistics Management, 24(4). Pp 1-68.

Allen, J., \& Rigby, D (2005). The Consumer of 2020. Global Agenda, 3(1), 172-175.

Allen, J. (2005). Closing the Delivery Gap-Brain and Company. www.bain.com/bainweb/pdf/cms.hottopics/closingdeliverygap.pdf

Auguste, B. G., Hdrmm, E. P., \& Pandit V. (2006). The Right Service Strategies for Product Companies. Mckinsey Quarterly, 44-57.

Barrett, A. (2005). Vanguard Gets Personal. Business Week, October, 115-118

Berkowitz E. N., Kerin R. A, Hartley, S.W., \& Rudelius W. (2000). Marketing (6 ${ }^{\text {th }}$ edition.). Boston Irwin McGraw Hill.

Berry, L. (1986). Big Ideas in Service Marketing. Journal of Consumer Marketing, 3(2), 47-51.

Berry, L. L., Lefkowith, E. F., \& Clark, T. (1988). In Service, What's in a Name? Harvard Business Review. 66(September-October), 28-30. 
Berry, L., \& Bendapudi, N. (2003). Clueing in Customer. Harvard Business Review, 81(2), 100-106.

Berry, L., \& Selman, K. D. (2003). Building a Strong Services Brands. Lessons from May Clark. Business Horizon, May-June, 198-209.

Bitner Jo, M. (2001). Self Service Technologies: What Do Customers Expect. Marketing Management, 32(1), 10-11.

Blodgett, G. J., \& Anderson, R. D. (2000). A Bayesian Network Model of the Customer Complaints Process. Journal of Service Research, 2(4), 321-38.

Business Day. (2013). Stock Market Update as at Friday 28 July. Retrieved Monday, 8 July from www.businessdayonline.com

Clift, V. (1995). Everyone Needs Service Flow Charting. Marketing News, 29(22), 41-43.

Copacino, W. C (1997). Supply Chain Management Boca Raton. FL: St. Lucie Press.

Donovan, D. T., Brown, T. J., \& Mowen, J. C. (2004). Internal Benefits of Service Worker Customer Orientation: Job Satisfaction, Commitment, and Organizational Citizenship Behaviours. Journal of Marketing, 68, 128-146.

Drug, Bartholomew (1998). It Delivers for Ups Industry Work (December), P60-63.

Ezejelue, A. C., Ogwo E. O., \& Nkamnebe A.D. (2007). Basic Principles in Managing Research Projects( $2^{\text {nd }}$ ed.) Aba -Nigeria Afritowers Limited.

Fornell, Claes \& Wernerfelt, B. (1998). A Model for Customer Complaints Management. Marketing Science, 7, 271-86.

Freunnd, J. E. (1967). Mathematical Statistics, Englewood Cliffs. New Jersey: Prentice Hall.

Gilly, M. C., \& Wolfinebarger, M. (1998). Advertising's internal Audience. Journal of Marketing, 62(1), 69-88.

Gooley, T. B. (1996). How Logistics Drive Customer Service. Traffic Management, 46.

Green, W. E., Walls; G. D., \& Schrest, L. J. (1994). Internal Marketing: The Key to External Marketing Success. Journal of Service Marketing, 8(4), 5-13.

Gronoos, C (1984). A Service- Quality Model and Its Marketing Implications. European Journal of Marketing, 18(4), 36-44.

Gronroos, C. (1984). Internal Marketing Theory and Practice. In Times Bloch, G. D. Upah \& V. A Zeithaml. Services Marketing in a Changing Environment. Chicago: American Marketing Association.

Hartline, M. D., \& Ferrell, O. C. (1996). The Management of Customer-Constant Service Employees: An Empirical Investigation. Journal of Marketing, 60, 52-70.

Hauser, J. R., Simester, D. I., \& Wernerfelt, B. (1996). Internal Customers and Internal Suppliers. Journal of Marketing Research, XXXIII (August 1996), 268-280.

Hertz S. (2003). Straight Development of the Third Party Logistics providers. Retrieved from elogistics.ihu.edu.tw/may/course/92_1/logistics/mildterm/20pdf

Hur, M. K., \& Tse D. K. (1996). What to Tell Consumers in Waits of Different Lengths: An Integrative Model of Service Evaluation. Journal of Marketing, 60(2), 81-90.

Jajah, C. (2011) ICT has Enhanced Ifex in Effective Mail Delivery. Retrieved from http://www.Nigeriacommunicationsweek.com.ng/details.php?category ....

Jang de, A., Ruyter de K., \& Lemmink J. (2004). Antecedents and Consequence of the Service Climate of Boundary -Spanning Self-management Service Teams. Journal of Marketing, 68(April), 18-35.

Johnson, K. (1997). A Flip Bride to E-Z Pass: East River Tolls and Rush Honour Prices. Times. August, P.21. The New York.

Kotler, P., \& Keller, K .L. (2009). Marketing Management(13th edition.). London: Pearson Education Ltd.

Lele, M. M., \& Karmarkar, U. S. (1983). Good Product Support is Smart Marketing. Harvard Business Review, 61(Nov-Dec), 124-132.

Levy, M., \& Weitz, B. A. (1998). Retailing Management ( $3^{\text {rd }}$ ed.). New York: Irwin McGraw- Hill.

Lieb, R. C., \& Maltz, A. (1998). What's that Future for Third Party Logistics? Supply Chain management Review, Spring, 71-79. 
Lovelock, C. (1991). Service Marketing. Pp 122-127. Englewood Cliffs, NJ: Prentice Hall.

Marcon, C., \& Macfarland, D. (2002). "Growth by Marketing Under the Radar" Presentation made at Marketing Science Institute. Board of Trustees Meetings Pathways to Growth, Tucon, AZ November.

Martilla, J. A., \& James, J. C. (1977). Importance-Performance Analysis. Journal of Marketing, 41(1), 77-79.

McGregor, Jena. (2007). Customer Service Champs. Pp 52-64, March. Business Week.

Meuter, M. L, Ostrom, A. L, Roundtress, R. J., \& Bitner, Jo M. (2005). Self Service Technologies: Understanding Customer Satisfaction with Technology-Based Service Encounters. Journal of Marketing, 64(3), 50-64.

Meuter, M. L., Bitner Jo M., Ostrom, A. L., \& Brown, S. W. (2005). Choosing among Alternative Service Delivery Modes: An Investigation of Customer Trial of Self -Service Technologies. Journal of Marketing, 69(2), 61-83.

Nikon. (2008). Focuses on Supply Chain Innovation and Makes New Product Distribution Soap Ups Case Study. Retrieved July 2008 from www.ups.scs/com/situations/case-studies/cs-nikon.pdf

Onkvisit, S., \& Shaw, J. J. (1989). Service Marketing: Image, Branding and Competition. Business Horizons, 32(1), 13-18.

Oren, H. (1993). Branding Financial Services Helps Consumers Find Order in Class. P6. March Marketing News.

Roger, Morton. (2007). Keeping the Supply Chain in Focus. July P12. Logistics Today.

Scheuing, E. (1989). Conducting Customer Service Audits. Journal of Consumer Marketing, 35-41.

Singh, J. (2000). Performance Productivity and Quality of Frontline Employees in Service Organizations. Journal of Marketing, 64(2), 15-34.

Sasser, E. W., Olsen P. R., \& Wyckoff, D. D. (1978). Management of Service Operations: Text, Cases, and Readings. Boston, MA: Allyn and Bacon.

Tansuhaj, P., Randall, D., \& McCullough, J. (1998). A Service Marketing Management Model: Integrating Internal and External Marketing Functions. Journal of Sciences Marketing, 2(1), 31-38.

Tarter, J. (2002). Service Marketing: The Relationship Factor. The Association of Support Professionals. Retrieved from www.asponline.com

Tax, S. S., \& Broun, S. W. (1998). Recovering and Learning from Service Failures. Sloan Management Review, 40(1), 75-88.

Taylor, S. (1994). Waiting for Service: The Relationship between Delays and Evaluation of Service. Journal of Marketing, 58(2), 56-69.

Bitner, M.J., Booms, B.H., \& Tetreault, M.S. (1990). The service encounter: diagnosing favourable and unfavourable incidents. Journal of Marketing, 54(1), 71-84.

Thomas, Dan R. E. (1978). Strategy is Different in Success Businesses. Harvard Business Review, July -August, $158-65$.

Thull, J. (2010), "How to Close a Sale"/Inc.com-Small Business Ideas. www.Inc.com./guide.2010/05 Retrieved from www.the prime solution.com./sales

- (2011). Marketing Essays-Nigeria Mail Market. Retrieved from http://www.ukessays.com/essays/marketing/Nigeria-mail-market. php

- (2013).Survey Finds Third -Party Logistics CEOs Projects Growth Amidst. Retrieved from www.prnewswire.com/.../finds-third-party logistics-cross-project...

- Top 25 Third Party Logistics Providers Extend Their Global Reach. Retrieved from www.supplychainbrain.com.service-third-party-logistics/...top-25.thir...

- (2013). 3PL Perspectives: Drafting a Blueprint for Growth-Inbound. Retrieved from www.inboundlogistics.com/...2013-3pl-perspectives-drafting-a-blueprin--

- (2013). Inbound Logistics Magazine's Market Research Shows Third -Retrieved from Party...finance yahoo.com/....inbound-logistics-magazines-market-research

- (2014). Third Party LogisticsStudy- Retrieved from www.capgemini.com/resource-file.../3pl_study_report_web_version pdfcurrent state of the 3pl.market... 
- Third Party Logistics-Key to Rail Freight Development in China. Retrieved from www.jrtr.net/jrtr29/f32_jia.html

- (2009). Third Part Logistics: Results and Finding of the 14th Annual. Retrieved from www.sci.gatech.edu/research/supply-chain/20093PLReport pdf later chapter

- (2013). Third -Party Logistics Study-Manufacturing Supply Chain. Retrieved from manufacturing.sco-summit.com/2014/cn/data/reports/file/1.pdf Current state of the 3PL. Market

- Market Efficiency /Freight Transport for Development- Retrieved from ppiaf.www.ppiaf.org/freighttoolkit/knowledge-map/logistics/market-efficiency 